\title{
Improving the Corrosion Resistance of Tin-bronze by Surface Modification
}

\author{
Mahmoud Abbas ${ }^{1}$, Reda F. M. Elshaarawy ${ }^{2}$, Rehab M. El-Maghraby ${ }^{1}$ and Esraa Hassan ${ }^{1}$ \\ ${ }^{1}$ Faculty of Petroleum and Mining Engineering, Suez University, Suez, Egypt. \\ ${ }^{2}$ Faculty of Science, Suez University, 43533 Suez, Egypt.
}

\begin{abstract}
:
Bronze alloys are made of copper-based materials with another metal, usually tin. Many surface modification techniques such as chemical etching, oxidation, electro deposition and sol-gel could be employed to improve surface properties. The organic compound that was used in this study was extracted from chili peppers. FT-IR (Fourier-transform infrared) spectroscopy and UV (Ultraviolet) spectroscopy investigations were applied on the extracted compound and results showed that this compound is mainly capsaicin [N-(4-hydroxy-3-methoxybenzyl)-8-methylnon-trans-6-enamide) (HMMTE)]. Electrochemical deposition was employed under cell voltage equal to 30 volts in a two-electrodes cell where bronze was the anode and stainless steel was the cathode in a solution of $10 \mathrm{ml} / \mathrm{L}$ (HMMTE)/distilled-water.

Modification of tin-bronze for $1 \mathrm{hr}$. in $10 \mathrm{ml} / \mathrm{L}$ HMMTE/ distilled water solution increased the contact angle from $48^{\circ}$ to $132^{\circ}$. Attension Biolin device (Model: Theta Optical Tensiometers) was used to measure the contact angle at ambient temperature. Electrochemical measurements revealed that a significant improvement in corrosion resistance of tin-bronze in $3.5 \% \mathrm{NaCl}$ had been achieved. The corrosion rate of tin-bronze decreased from 10.22 mpy to 1.39 mpy. Surface morphology of the samples was investigated with scanning electron microscopy (SEN) and energy-dispersive X-ray (EDX). X-ray diffraction was employed to determined present phases. Surface investigations results confirmed that a layer of red cuprous oxide (Cu2O) was formed on the surface layer after modification which led to the improvement in corrosion resistance. Salt spray test was carried out using Alpha+ Salt Spray Testing Equipment for 13 days on the base and surface modified samples according to ASTM B117. A green layer from $[\mathrm{CuCl} 2$ and $\mathrm{Cu} 46 \mathrm{Cl} 24(\mathrm{OH}) 68-(\mathrm{H} 2 \mathrm{O}) 4]$ was observed on the nonmodified specimen (could be patina and bronze disease) while the red layer [Cu2O] is still observed on the modified specimen. Adhesion test (using X-Cut Tape Adhesion test according to ASTM D3359) was also investigated.
\end{abstract}

\section{Keywords:}

Tin-Bronze, Surface modification, Cupric and Cuprous oxides, Contact angle, Corrosion.

\section{Introduction}

Tin Bronze alloys consist of copper with the major alloying element being tin. The existence of tin provides high mechanical properties ${ }^{[1-2]}$. Bronze can be used in an extraordinary range of applications, some of these applications include electrical contacts, ship propellers, machine tools and some bearings, springs, coins, and pump impellers ${ }^{[3]}$. CuSn bronzes are also used in various application areas including electronics and networking sectors, musical instruments, and medals, and in industrial 
applications such as bushings and bearings ${ }^{[4-6]}$, art foundry or archeological artifacts ${ }^{[7]}$. Bronze resists metal fatigue better and conducts heat and electricity better than most steels ${ }^{[8,9]}$.

Like copper, bronze can form a patina, a green film as a result of long exposure to moist air. Bronze will crumble rapidly if exposed to moisture and chlorides or sulfides ${ }^{[10-14]}$. Bronze is susceptible to "Bronze Disease "one of the most serious hazards of bronze. The disease is happened as chlorides and oxygen combine in a humid environment and attacks bronze. The disease can be recognized when sudden outbreak of small patches of corrosion, rough, light green spots, forms on the bronze piece ${ }^{[15-}$ ${ }^{17]}$. Many surface modifications techniques such as chemical etching ${ }^{[18]}$, oxidation ${ }^{[19]}$, inhibitors, sol-gel ${ }^{[20,21]}$, and electrodeposition ${ }^{[22,23]}$ could be used to improve the corrosion resistance of tin-bronze. Recently, demand for environmentally friendly corrosion protection techniques has become urgent. Extracts of plants, such as Phyllanthus amarus, Salvia officinalis ${ }^{[24]}$ bamboo ${ }^{[25]}$, and others ${ }^{[26-31]}$ were reported to act as effective inhibitors to metal corrosion.

There are several papers concerned about using organic compounds for improving the corrosion resistance of copper, bronze, and brass. According to M. Abbas, et. al. stearic acid can be used to improve the surface properties of copper by forming $\mathrm{Cu}_{2} \mathrm{O}$ on the copper surface ${ }^{[32,33]}$.

O.R.M. Khalifa, A.K. Kassab and et.al showed that the addition effect of organic compounds containing an amino group, like ethylamine (EA) and butanediamine (BDA), on the corrosion of copper and copper alloy in nitric acid. Results obtained exposed that butanediamine is the best inhibitor and the protection efficiency $(\mathrm{p} \%)$ pursues the sequence butanediamine > ethylenediamine > ethylamine ${ }^{[34]}$.

In addition, M. Hasanin and et.al investigated the impact of novel corrosion inhibitors based on biopolymer that were synthesized in-situ using different cellulosic materials and niacin. Potentiodynamic polarization measurements confirmed that cellulose-based inhibitors act as a mixed type green corrosion inhibitor for copper in 3.5\% $\mathrm{NaCl}$ solutions. The inhibition efficiency of ethyl cellulose -niacin composite (NEC) was $94.7 \%$ which outperforms those of microcrystalline cellulose -niacin composite (NMCC) and carboxymethyl cellulose -niacin composite (NCMC) which were 33.2 and $83.4 \%{ }^{[35]}$.

The target of this work was to develop simple and inexpensive approach for the formation of protective and good adhesion oxide film for Tin-bronze corrosion control by using environmentally friendly compounds.

\section{Materials and Methods}

\subsection{Materials}

As shown in Table 1, X-ray fluorescence (XRF) Spectrometer (Model NITON XL3 T980 GOLD) was used for conducting analysis of the samples. Tin-bronze samples were in the form of plates with dimensions $20 \times 10 \mathrm{~cm}$. Each plate was cut into specimens with area of $1 \mathrm{~cm}^{2}$ cross section and $1 \mathrm{~cm}$ height for the microscopic investigation and electrochemical experiments.

Table 1: chemical composition of tin-bronze sample

\begin{tabular}{|l|l|l|l|l|l|}
\hline Element & $\mathrm{Cu} \%$ & $\mathrm{Sn} \%$ & $\mathrm{Fe} \%$ & $\mathrm{Zn} \%$ & $\mathrm{~Pb} \%$ \\
\hline Composition Wt\% & 93.13 & 6.223 & 0.059 & 0.129 & 0.054 \\
\hline
\end{tabular}

\subsection{Capsaicin preparation}

The chili peppers were dried then powdered. The pulverized pepper was placed in a jar containing ethanol which acts as a solvent. This mixture was left for a week then filtered to separate the pepper bits and sediment from the residual liquid. The 
liquid was left for another week in a well-ventilated area to produce a concentrated amount of the active ingredient; capsaicin (see Figure 1). The concentrate was examined by FT-IR (Fourier-transform infrared) spectroscopy and UV (Ultraviolet) spectroscopy.<smiles>COc1cc(CNC(=O)CCCC/C=C/C(C)C)ccc1O</smiles>

Fig. 1: molecular structure of HMMTE

As shown in Figure 2, the FT-IR spectrum of the pepper extract, a sharp absorption band can be observed at $3310 \mathrm{~cm}^{-1}$ which can be assigned to the stretching vibration of the (N-H) group. A very broad band at the range $3500-2500 \mathrm{~cm}^{-1}$ could be ascribed to the phenolic $(\mathrm{O}-\mathrm{H})$ moiety. In addition, the plant extract sample showed two types of aliphatic $(\mathrm{C}-\mathrm{H})$ stretching vibrations at 2928 and $2867 \mathrm{~cm}^{-1}$. Moreover, the presence of the $(\mathrm{C}=\mathrm{O})$ group could be confirmed from the notice of a stretching vibration peak at $1629 \mathrm{~cm}^{-1}$. The strong stretches observed at the range of $\left(1559-1419 \mathrm{~cm}^{-1}\right)$ are assigned to stretching vibration of $(\mathrm{C}=\mathrm{C})$ in the phenyl ring. Furthermore, the peaks characteristic for the aryl-O and bending out-of-plane $(\mathrm{C}-\mathrm{H})$ can be observed at 1282 and $806 \mathrm{~cm}^{-1}$, respectively. Also, a vibration observed at $1239 \mathrm{~cm}^{-1}$ is due to the asymmetric stretching vibration of (C-O-C). These IR spectral data fully agree with that previously reported for standard capsaicin ${ }^{[36,37]}$.

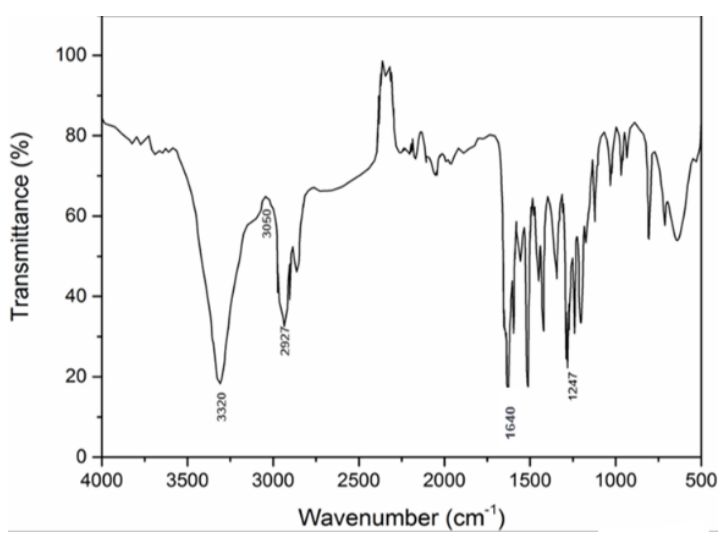

(a)

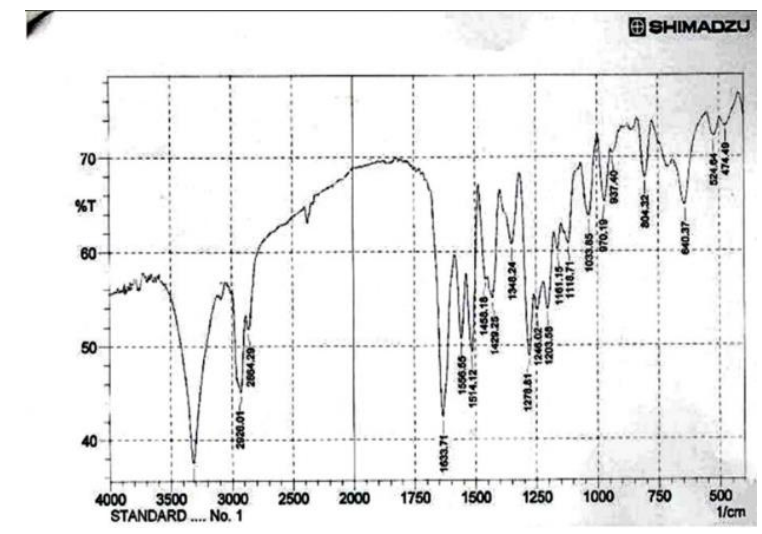

(b)

Fig. 2: IR results of (a) extracted capsaicin and (b) standard capsaicin.

Further evidence for the success of capsaicin extraction and its purity is the ultraviolet absorption spectrum (Figure 3). The two main UV peaks observed at 222 and $280 \mathrm{~nm}$ could be ascribed to the $\pi \rightarrow \pi^{*}$ and $\mathrm{n} \rightarrow \pi^{*}$ electronic transitions characteristic for the capsaicinoid segment of capsaicin. Also, these findings are fully agreeing with that previously reported for standard capsaicin ${ }^{[38]}$.

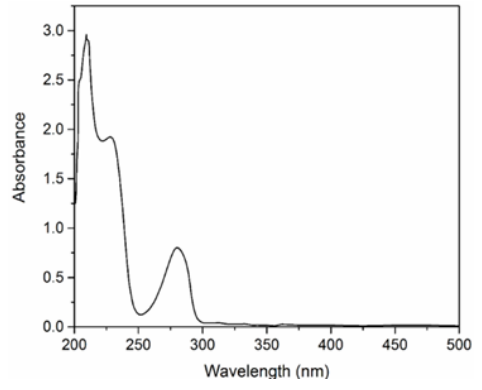

(a)

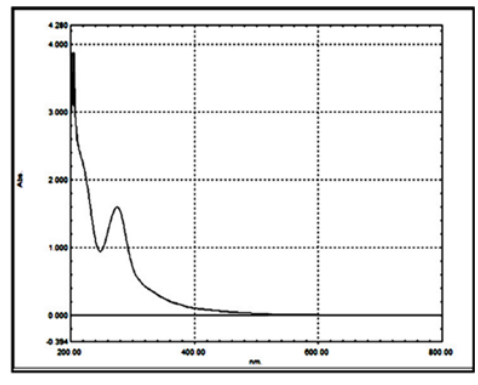

(b)

Fig. 3: UV results of (a) extracted capsaicin and (b) standard capsaicin. 


\subsection{Specimen preparation}

Specimens were ground progressively using wet silicon carbide ( $\mathrm{SiC}$ ) emery papers with grit number starting with 600-grit and proceeding to 2000- grit papers. Water was used to retain specimens cool and to flush away loose particles of metal and abrasive. After that, samples were rinsed using distilled water and acetone, and then air dried.

\subsection{Surface Modification Technique}

Tin-bronze specimen with an area of $1 \mathrm{~cm}^{2}$ was abraded with emery paper up to 2000 grit, degreased with ethanol, and then blow dried. Hydrophobic film was grown in a two-electrode cell, see Figure 4, with tin-bronze specimen as anode and stainlesssteel plate as cathode. A $10 \mathrm{ml} / \mathrm{L}$ HMMTE/distilled water solution was used as electrolyte. Film was formed by applying a cell voltage of 5-30 V between anode and cathode at room temperature from $30 \mathrm{~min}$ to $2 \mathrm{~h}$. An uninterrupted DC power system was used to supply the constant voltage. After electrolysis, tin-bronze specimen was brought out then washed with ethanol.

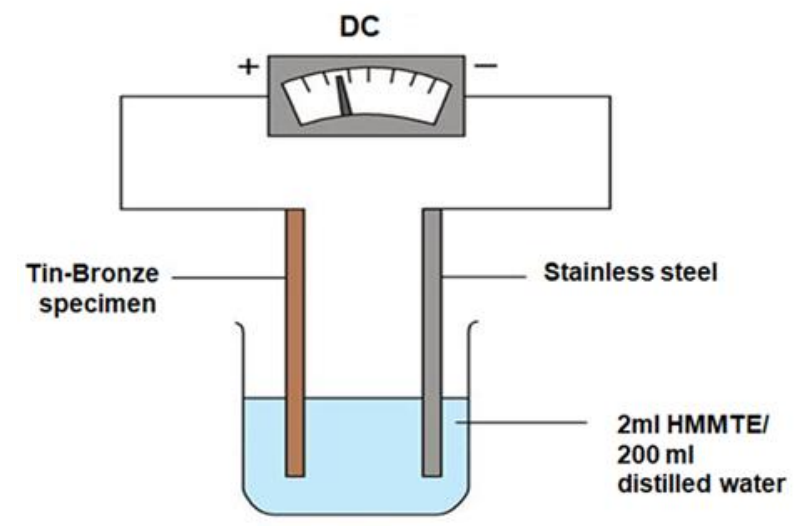

Fig. 4: The electrochemical cell of surface modification of bronze.

\subsection{Characterization}

An optical microscope (OPTIKA), a scanning electron microscopy (SEM, FEI Inspect S50), and X-ray diffraction (XRD, Bruker, discover D8 Advance) had been used to investigate the surface morphologies and chemical compositions of the samples. The contact angle was measured by Attension Biolin device (Model: Theta Optical Tensiometers) using double distilled water with $5 \mu$ liter drop size at room temperature. Electrochemical corrosion behavior was conducted in $3.5 \mathrm{wt}$. \% $\mathrm{NaCl}$ aqueous solution via versa stat device at room temperature. The workstation was equipped with a standard three-electrode system: graphite electrode was used as the counter electrode, the calomel electrode (SCE) was used as the reference electrode, while the tin-bronze sample was used as the working electrode. For achieveing a stable open circuit potential (OCP vs. SCE), tin-bronze samples were immersed in the $\mathrm{NaCl}$ solution for $20 \mathrm{~min}$. Before begaining the electrochemical experiments. The potentiodynamic polarization curves were measured between $-0.15 \mathrm{~V}$ and $0.15 \mathrm{~V}$ (vs. OCP) with the scanning rate of $0.5 \mathrm{mV} / \mathrm{s}$. In addition, adhesion was carried out using Tape adhesion Test (X-Cut) ASTM D3359 ${ }^{[39]}$. 


\section{Results and Discussions}

\subsection{Contact Angle Measurement}

Contact angle was measured for each sample before and after surface modification. Surface modification was conducted for different timing; 0, 30, 60, 90 and 120 minutes and the corresponding contact angle was measured respectively, see Figure 5. Results show that the contact angle increases with the increase in surface treatment length till a maximum of $132^{\circ}$ contact angle is reached after $1 \mathrm{hr}$ then it decreases again. This contact angle measurements reflect the formation of a hydrophobic film on the tin-bronze surface after 1 hour of surface treatment. However, the decrease in contact angle after further treatment may be attributed to the formation of different compounds as the length of surface treatment increases due to the reaction of tin-bronze with the active ingredient capsaicin.

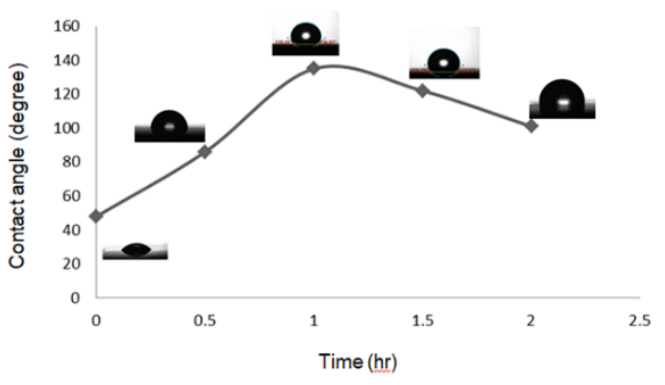

Fig. 5: Effect of surface modification time on contact angle

\subsection{Corrosion Measurements}

Results from the potentiodynamic polarization tests of all modified specimens are given in Table 2 and illustrated in Figures 6. It could be observed that treating for $1 \mathrm{hr}$. gave the lowest corrosion rate which agrees with the results obtained from the contact angle measurements.

Table 2: corrosion parameter of modified samples at different time

\begin{tabular}{|l|l|l|l|l|}
\hline \multicolumn{2}{|l|}{ condition } & $\mathrm{E}_{\text {corr }}(\mathrm{V})$ & $\mathrm{i}_{\text {corr }}(\mu \mathrm{A})$ & $\mathrm{C} . \mathrm{R}(\mathrm{mpy})$ \\
\hline Pure & -0.266 & 17.651 & 10.22 \\
\hline \multirow{2}{*}{\begin{tabular}{l} 
Modified in $\begin{array}{l}2 \mathrm{ml} \\
\text { cap./200ml } \\
\text { distilled water }\end{array}$ \\
\cline { 2 - 5 }
\end{tabular}} & $1.5 \mathrm{hr}$ & -0.2456 & 16.669 & 7.18 \\
\cline { 2 - 5 } & $2 \mathrm{hr}$ & -0.273 & 1.838 & 1.39 \\
\hline
\end{tabular}




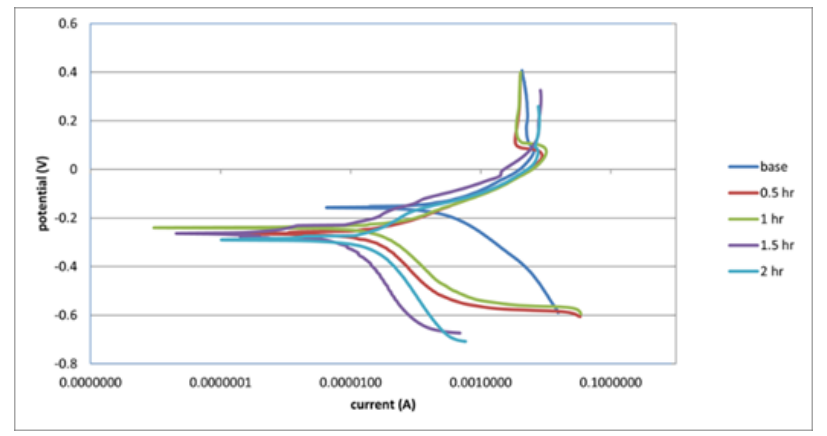

Fig. 6: Polarization curves of base and modified samples at different times.

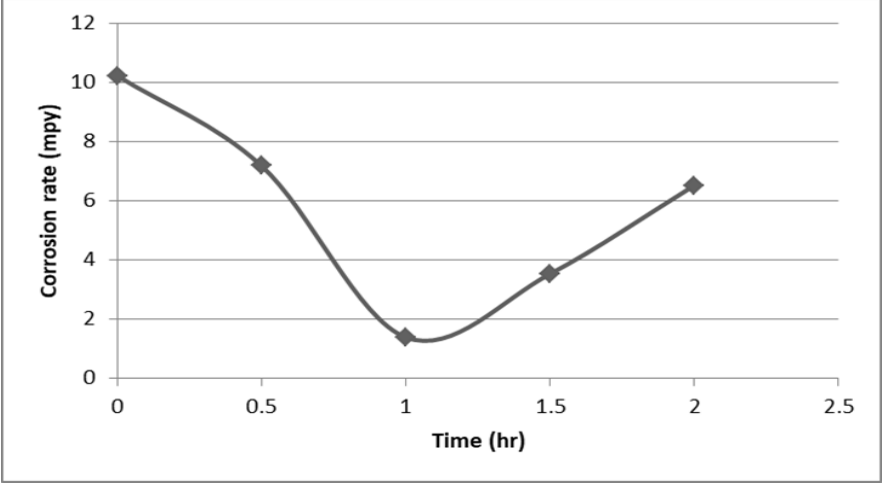

Fig. 7: Variation of corrosion rate of modified tin-bronze in 10ml/L HMMTE/distilled water at different times

\subsection{Surface morphology}

The geometrical characteristics of the surfaces before and after treatment were investigated by SEM images. Figure 8-(a) shows the morphology of tin-bronze surface without any treatment. It is very smooth with a Contact Angle of $48^{\circ}$. After treatment for 1 hour in 10ml/L HMMTE/Distilled water solution, it could be observed that the surface was covered by a protective layer with a contact angle of $132^{\circ}$, as shown in Figure 8-(b). EDX investigation, Figure 9, showed that the formed film is mainly consists of copper, oxygen, and nitrogen due to the reaction of Capsaicin with bronze surface. EDX results showed that, the formed film Copper Wt. \% decreased due to the oxidation process which was carried during the surface modification process while Oxygen Wt. \% increased, as shown in Figure 8.

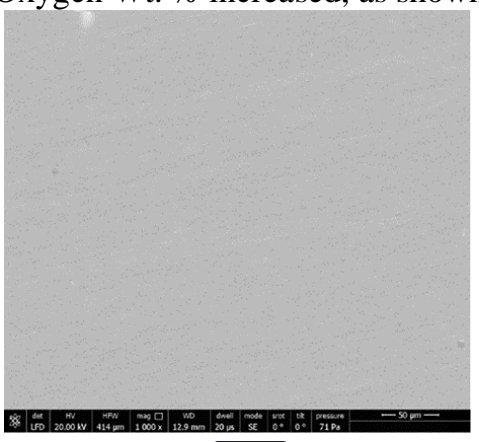

(a)

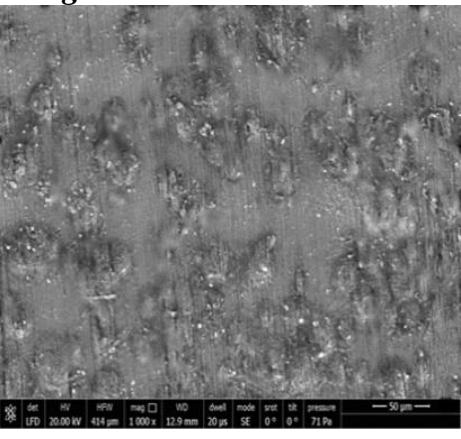

(b)

Fig. 8: SEM images of bare bronze(a) and surface treated sample for $1 \mathrm{hr}$. in 10ml/L HMMTE /Distilled water (b) 


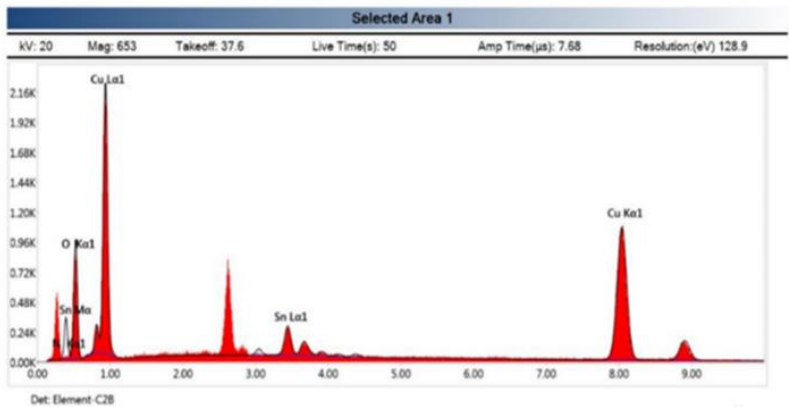

\begin{tabular}{cccc}
\multicolumn{4}{c}{ Smart Quant Results } \\
Element & Weight \% & Atomic \% & Error \% \\
\hline N K & 8.24 & 21.31 & 12.83 \\
\hline OK & 16.77 & 37.97 & 10.92 \\
\hline CuK & 67.31 & 38.38 & 3.04 \\
\hline SnL & 7.68 & 2.35 & 12.56 \\
\hline
\end{tabular}

Fig. 9: EDX analysis of modified sample with $10 \mathrm{ml} / \mathrm{L}$ HMMTE/distilled water solution for $1 \mathrm{hr}$.

\subsection{Salt spray test:}

The test was carried out by Alpha+ Salt Spray Testing Equipment. Two specimens are tested: base specimen and surface modified specimen for $1 \mathrm{hr}$. under test conditions, Chamber temperature is $35{ }^{\circ} \mathrm{C}$, $\mathrm{pH}$ is in the range of 6.5 to 7.2 and $5 \%$ sodium chloride aqueous solution was used. The test lasted for 13 days. This method is based on ASTM B117 ${ }^{[40]}$. It was found that the specimen which was surface treated in $10 \mathrm{ml} / \mathrm{L} \mathrm{HMMTE} /$ distilled water for $1 \mathrm{hr}$. under $30 \mathrm{~V}$ stands for 13 days under the test protected by the cuprous oxide film on its surface. However, the base specimen showed that copper chlorides compounds were formed on the surface which reflects that it was not protected. Note that one day in this test under these conditions equal almost a year in nature.

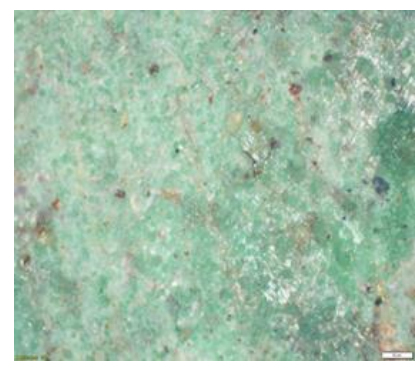

(a)

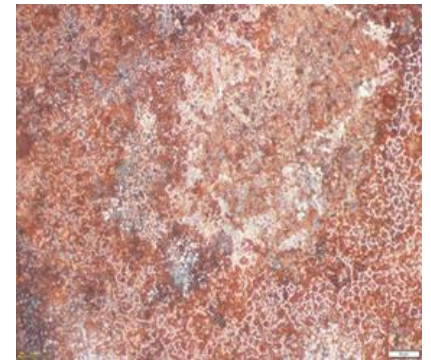

(b)

Fig. 10: Macrograph of tin-bronze samples after salt spray test lasted for 13 days (a) base specimen, (b) modified sample for $1 \mathrm{hr}$. before test.50x.

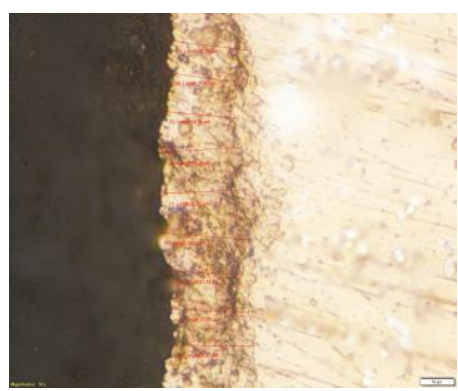

(a)

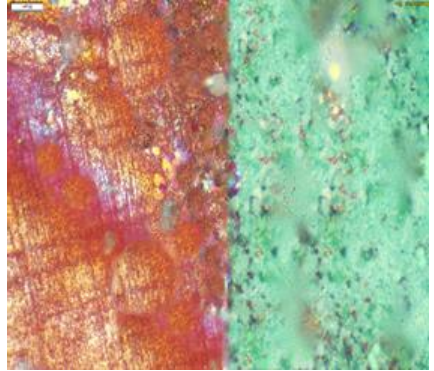

(b)

Fig. 11: Macrograph of a cross-section of protective $\mathrm{Cu}_{2} \mathrm{O}$ film and the base metal after salt spray test lasted for 6 (a) before test and (b) after test. 


\subsection{X-Ray Diffraction}

Different X-ray diffraction patterns for the specimens from the following conditions: base, specimen modified for $1 \mathrm{hr}$., blank after salt spray test and specimen modified for $1 \mathrm{hr}$. after salt spray test are shown in Figures 12, 13, 14 and 15 respectively. It is clear that, there is a change in the XRD when the $2 \theta$ ranged from $10^{\circ}$ to $100^{\circ}$. Copper, Oxygen, and nitrogen are the main composition of the film. Existence of nitrogen suggests that HMMTE exists in film. These results indicate that film on tinbronze surface essentially consists of $\mathrm{Cu}(\mathrm{II})$ coordinated with HMMTE.

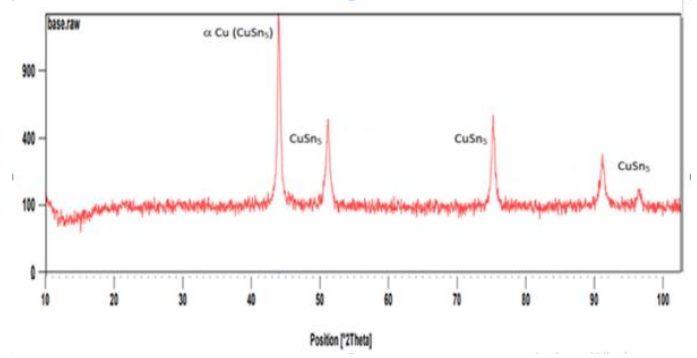

Fig. 12: XRD analysis of base Tin-bronze sample
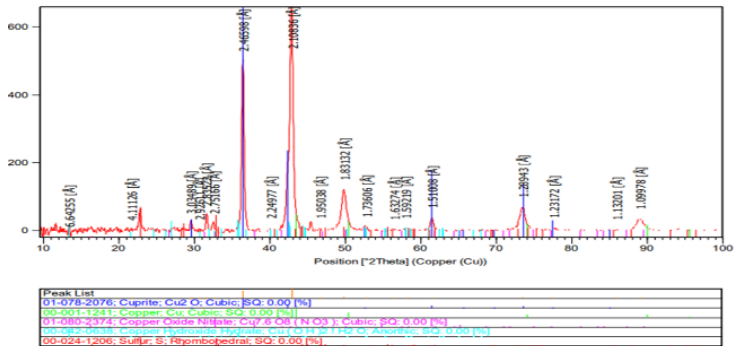

Fig. 13: XRD analysis of modified sample for $1 \mathrm{hr}$.

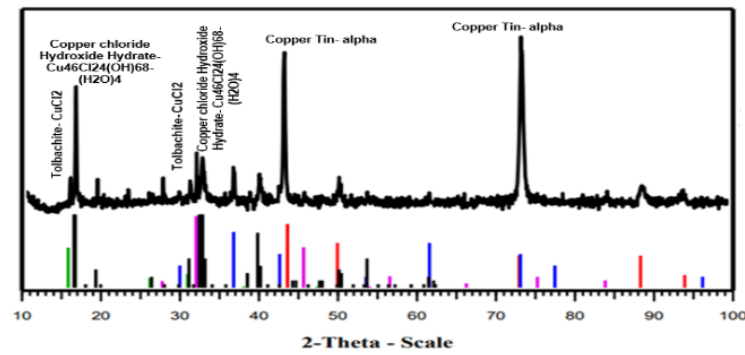

Fig. 14: XRD analysis of base tin-bronze sample after salt spray test lasted for 13 days.

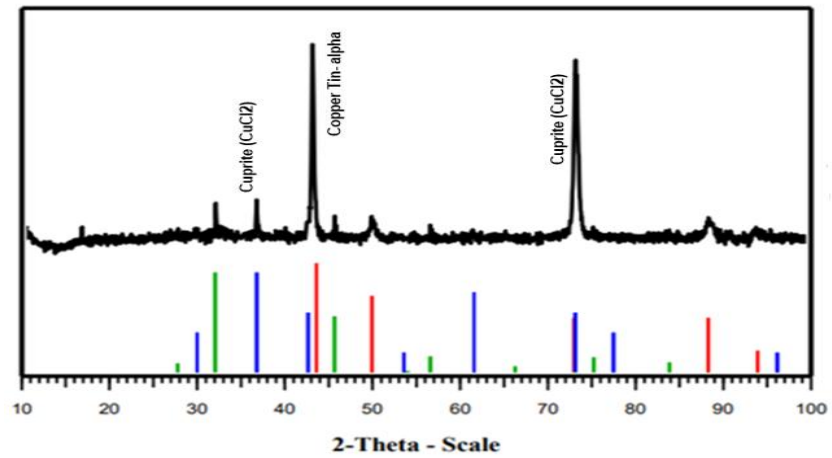

Fig. 15: XRD analysis of modified sample for $1 \mathrm{hr}$. after salt spray test lasted for 13 days. 


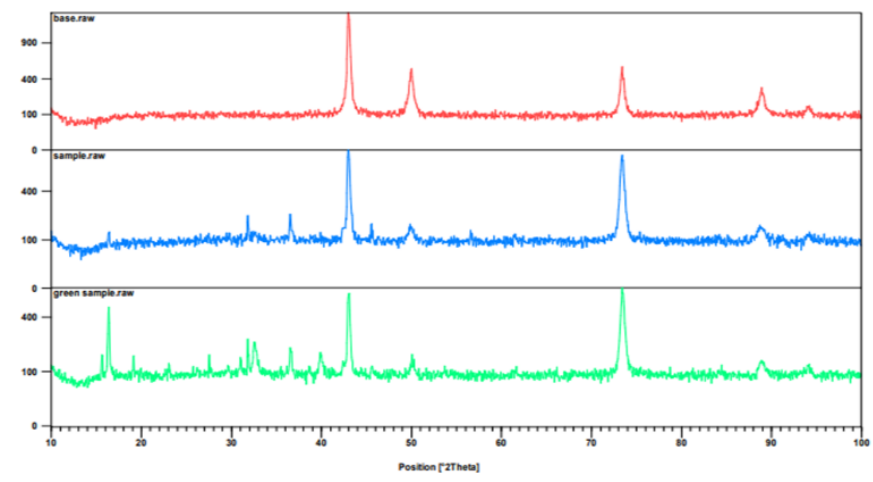

Fig. 16: EDX analysis of (a)base tin-bronze sample, (b) modified sample and (c) unmodified sample after salt spray test lasted for 13 days.

\subsection{Adhesion Test}

The adhesion tape test was carried out on the specimen with the most promising results; the $1 \mathrm{hr}$. surface modified tin-bronze specimen. Adhesion was carried out according to ASTM D 3359 method 13, thickness $<125 \mu \mathrm{m}$. It can be observed that, the surface in this condition had an excellent adhesion as shown in Figure 17. The adhesion of the film is classified as 5A which denote that there was no peeling or removal.

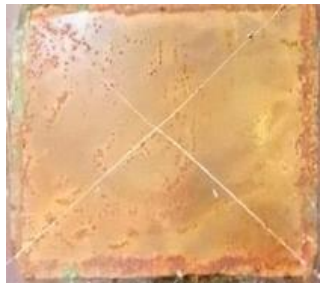

(a)

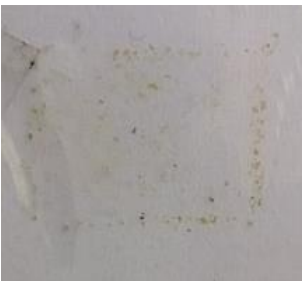

(b)

Fig. 17: Micrograph of specimens (a) modified sample and (b) test result ,10x.

\subsection{Running flow of $\mathrm{NaCl}$ test (Corrosion-erosion)}

Two specimens were used for the corrosion-erosion test: a base specimen and surface modified specimen for $1 \mathrm{hr}$. A device that simulates the conditions applied in industry was used for the calculation of corrosion-erosion rate according to ASTM G3.11. The corrosive media was 3.5\% NaCl. Corrosion rate decreased from 50.5 mpy for base metal to $24.7 \mathrm{mpy}$ for the $1 \mathrm{hr}$. surface modified specimen, see Figure 16 for the macrograph of both base metal and the $1 \mathrm{hr}$. surface modified specimen before and after test photos.

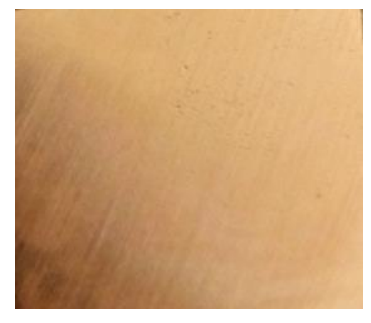

(a)

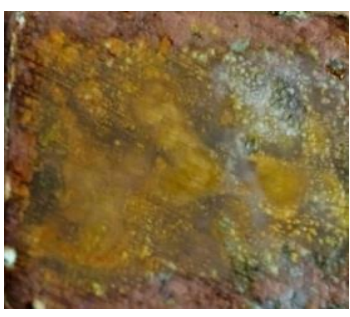

(b)

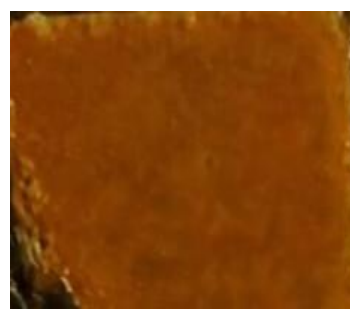

(c)

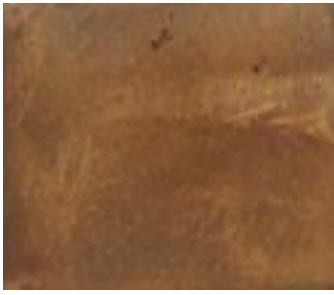

(d)

Fig. 18: Macrograph of specimens (a) base metal before test, (b) base metal after test, (c) modified sample before test and (d) modified sample after test, 10x. 


\section{Conclusions}

An extract of environmentally friendly compound was prepared. Both IR and UV techniques confirmed that the extracted compound is mainly capsaicin. It was observed that $\mathrm{Cu}_{2} \mathrm{O}$ film was formed on tin-bronze surface in an electrical circuit. Surface modification of tin-bronze in 10ml/L HMMTE/distilled water solution for $1 \mathrm{hr}$. formed a hydrophobic protective layer of contact angle $132^{\circ}$. While that of base was $48^{\circ}$ which shows an improvement in contact angle of about 3 folds.

Results from XRD, showed that Cuprous Oxide $\left(\mathrm{Cu}_{2} \mathrm{O}\right)$, Which is the most protective layer, is formed on the surface. The corrosion rate of bronze decreases from about $10.22 \mathrm{mpy}$ to about $1.39 \mathrm{mpy}$ after surface modification in $10 \mathrm{ml} / \mathrm{L}$ HMMTE/distilled water solution for $1 \mathrm{hr}$ using $30 \mathrm{~V}$. Improvement in corrosion rate is about 5 times. According to the running flow test, corrosion rate decreased from 50.5 mpy for base metal to 24.7 mpy for the modified specimen, showing an improvement in corrosion-erosion test of about 2 times.

For salt spray test, after 13 days a dense layer of corrosion product which is mainly patina was formed on the bronze surface while the radish layer which is $\mathrm{Cu}_{2} \mathrm{O}$ is still exists on the surface without any corrosion product as confirmed by XRD. According to ASTM D 3359 method 13, the adhesion of the film classified as 5A which denote that there was no peeling or removal.

\section{References}

[1] J. Muller, B. Laïk, I. Guillot, $\alpha$-CuSn bronzes in sulphate medium: influence of the tin content on corrosion processes, Corros. Sci. 77 (2013) 46-51.

[2] T. Chang, G. Herting, S. Goidanich, " The role of Sn on the long-term atmospheric corrosion of binary Cu-Sn bronze alloys in architecture", KTH Royal Institute of Technology, Division of Surface and Corrosion Science, School of Engineering Sciences in Chemistry, Biotechnology and Health, Dr. Kristinas v. 51, SE, 10044 Stockholm, Sweden, 2019.

[3] G. Ingo, T. De Caro, C. Riccucci, E. Angelini, S. Grassini, S. Balbi, P. Bernardini, D. Salvi, L. Bousselmi, M. Gener, Large scale investigation of chemical composition, structure and corrosion mechanism of bronze archeological artefacts from Mediterranean basin, Appl. Phys. A 83 (2006) 513-520.

[4] W. Pu, X. He, J. Ren, C. Wan, C. Jiang, Electrochim. Acta 50 (2005) 4140-4145.

[5] J.S. Thorne, J.R. Dahn, M.N. Obrovac, R.A. Dunlap, J. Power Sources 216 (2012) 139-144.

[6] R.M. Gnanamuthu, S. Mohan, C.W. Lee, Mater. Lett. 84 (2012) 101-103.

[7] T. Beldjoudi, F. Bardet, N. Lacoudre, S. Andrieu, A. Adriens, I. Constantinides, P.Brunella, Rev. Metall.-Paris 98 (2001) 803-808.

[8] W.J. Guo, S.H. Chen, B.D. Huang, H.Y. Ma, X.G. Yang, Electrochim. Acta 52 (2006)108.

[9] H. Leidheiser, (1979) “Aqueous Corrosion" in The Corrosion of Copper, Tin and Their Alloys, Robert E. Krieger Publishing Company, Huntington, NY, pp. $71-126$.

[10] C. Chiavari, K. Rahmouni, H. Takenouti, S. Joiret, P. Vermaut, L. Robbiola, Composition and electrochemical properties of natural patinas of outdoor bronze monuments, Electrochim. Acta 52 (2007) 7760-7769.

[11] A. Drach, I. Tsukrov, J. DeCew, J. Aufrecht, A. Grohbauer, U. Hofmann, Field studies of corrosion behaviour of copper alloys in natural seawater, Corros. Sci. 76 (2013) 453-464. 
[12] I. Odnevall Wallinder, X. Zhang, S. Goidanich, N. Le Bozec, G. Herting, C. Leygraf, Corrosion and runoff rates of Cu and three $\mathrm{Cu}$-alloys in marine environments with increasing chloride deposition rate, Sci. Total Environ. 472 (2014) 681-694.

[13] X. Zhang, I. Odnevall Wallinder, C. Leygraf, Mechanistic studies of corrosion product flaking on copper and copperbased alloys in marine environments, Corros. Sci. 85 (2014) 15-25.

[14] J. Muller, B. Laï, I. Guillot, $\alpha$-CuSn bronzes in sulphate medium: influence of the tin content on corrosion processes, Corros. Sci. 77 (2013) 46-51.

[15] "Archaeologies of the Greek Past: Bronze disease". Brown University. Retrieved 12 June 2020.

[16] N. Souissi, E. Sidot, L. Bousselmi, E. Triki, L. Robbiola, Corrosion behaviour of $\mathrm{Cu}-10 \mathrm{Sn}$ bronze in aerated $\mathrm{NaCl}$ aqueous media-electrochemical investigation, Corros. Sci. 49 (2007) 3333-3347.

[17] D. Šatovića, L. Valek Žuljb, V. Desnica, S. Fazinić, S. Martinez, Corrosion evaluation and surface characterization of the corrosion product layer formed on $\mathrm{Cu}-6 \mathrm{Sn}$ bronze in aqueous $\mathrm{Na}_{2} \mathrm{SO}_{4}$ solution, Corros. Sci. 51 (2009) 1596-1603.

[18] M. Ruan, W. Li, B. Wang, Q. Luo, F. Ma, Z. Yu, Optimal conditions for thepreparation of superhydrophobic surfaces on al substrates using a simpleetching approach, Appl. Surf. Sci. 258 (2012) 7031-7035.

[19] L. Liu, F. Xu, L. Ma, Facile fabrication of a superhydrophobic Cu surface via a selective etching of high-energy facets, J. Phys. Chem. C 116 (2012)18722-18727.

[20] D. Seifzadeh, E. Golmoghani- Ebrahimi, Formation of novel and crack free nano composites based on sol gel process for corrosion protection of copper, Surf. Coat. Technol. 210 (2012) 103-112.

[21] A.V. Rao, S.S. Latthe, S.A. Mahadik, C. Kappenstein, Mechanically stable and corrosion resistant superhydrophobic solgel coatings on copper substrate, Appl. Surf. Sci. 257 (2011) 5772-5776.

[22] Z. Chen, L.M. Hao, A.Q. Chen, Q.J. Song, C.L. Chen, A rapid one-step process for fabrication of superhydrophobic surface by electrodeposition method, Electrochim. Acta 59 (2012) 168-171.

[23] Z.X. She, Q. Li, Z.W. Wang, L.Q. Li, F.N. Chen, J.C. Zhou, Novel method for controllable fabrication of a superhydrophobic CuO surface on AZ91Dmagnesium alloy, ACS Appl. Mater. Interfaces 4 (2012) 4348-4356.

[24] N. Soltani, N. Tavakkoli, M. Khayatkashani, M.R. Jalali, A. Mosavizade, Green approach to corrosion inhibition of 304 stainless steel in hydrochloric acid solution by the extract of Salvia officinalis leaves, Corros. Sci. 62 (2012) 122-135.

[25] X. Li, S. Deng, H. Fu, Inhibition of the corrosion of steel in HCl, H2SO4 solutions by bamboo leaf extract, Corros. Sci. 62 (2012) 163-175.

[26] O.K. Abiola, A.O. James, The effects of Aloe vera extract on corrosion and kinetics of corrosion process of zinc in $\mathrm{HCl}$ solution, Corros. Sci. 52 (2010) 661-664.

[27] O.K. Abiola, J.O.E. Otaigbe, O.J. Kio, Gossipium hirsutum L. extracts as green corrosion inhibitor for aluminum in $\mathrm{NaOH}$ solution, Corros. Sci. 51 (2009)1879-1881.

[28] P.B. Raja, A.K. Qureshi, A.A. Rahim, H. Osman, K. Awang, Neolamarckia cadamba alkaloids as eco-friendly corrosion inhibitors for mild steel in $1 \mathrm{M} \mathrm{HCl}$ media, Corros. Sci. 69 (2013) 292-301.

[29] X. Li, S. Deng, Inhibition effect of Dendrocalamus brandisii leaves extract on aluminum in HCl, H3PO4 solutions, Corros. Sci. 65 (2012) 299-308. 
[30] S. Deng, X. Li, Inhibition by Jasminum nudiflorum Lindl. leaves extract of the corrosion of aluminium in $\mathrm{HCl}$ solution, Corros. Sci. 64 (2012) 253-262.

[31] L. Li, X. Zhang, J. Lei, J. He, S. Zhang, F. Pan, Adsorption and corrosion inhibition of Osmanthus fragran leaves extract on carbon steel, Corros. Sci. 63 (2012) 82- 90.

[32] Mahmoud I. Abbas, Rehab Maghraby, Adel M. A. Mohamed and Ibtehal Hamed, "Improving Corrosion Resistance of Copper by Forming Super Hydrophobic Layer on Surface", Faculty of Petroleum and Mining Eng., Suez University, Suez, Egypt (2018). [46] "Capsaicin". ChemSpider, Royal Society of Chemistry, Cambridge, UK. 2018. Retrieved 9 June 2018.

[33] D. Knotkova \& K. Kreislova, "Atmospheric corrosion and conservation ofcopper and bronze", SVUOM Ltd., Prague, Czech Republic, 2007.

[34] O.R.M. Khalifa, A.K. Kassab, H.A. Mohamed and S.Y. Ahmed, "Corrosion Inhibition of Copper and Copper Alloy in 3M Nitric Acid Solution using Organic Inhibitors", Chemistry department, Faculty of Girls for Arts, Science and Education, Ain shams University, Cairo, Egypt 2010.

[35] Mohamed S. Hasanin and Sherief A. Al Kiey, "Environmentally benign corrosion inhibitors based on cellulose niacin nano-composite for corrosion of copper in sodium chloride solutions",Cellulose and paper Department, National Research Centre, Dokki, Cairo 12622, Egypt 2020.

[36] J.S.P. Leela, R. Hemamalini, S. Muthu, A.A. Al-Saadi, Spectroscopic investigation (FTIR spectrum), NBO, HOMOLUMO energies, NLO and thermodynamic properties of 8-Methyl-N-vanillyl-6-nonenamideby DFT methods, Spectrochimica Acta Part A: Molecular and Biomolecular Spectroscopy 146 (2015) 177-186.

[37] A.E. Ekhlas, N.A. Zahra, A.J. AI-Anny, FT-IR Identification of Capsaicin from callus and seedling of chilli pepper plants Capsicum annuum L. in vitro, Int. J. of Multidisciplinary and Current research, 4 (2016) 1144-1146.

[38] A. Shrivastava, P. Saxena, Stability indicating reverse phase high performance liquid chromatography method for the estimation of capsaicin, Pharmaceutical Methods 2 (2011) 135-142.

[39] ASTM-D3359, "Standard Test Methods for Measuring Adhesion by Tape Test"(2002).

[40] ASTM B117, “Standard Practice for Operating Salt Spray (Fog) Apparatus” (2011). 